\title{
THE EFFECT OF MOTIVATION ON PURCHASING INTENTION OF ONLINE GAMES AND VIRTUAL ITEMS PROVIDED BY ONLINE GAME PROVIDER
}

\author{
Sisca Stefany \\ PT Artha Boga Cemerlang \\ Jl Lingkar Luar Barat Kav 35-36, Jakarta 11740, Indonesia \\ sisca_stefany2000@yahoo.com
}

\begin{abstract}
The development of online games is so high that leads many companies to compose games. To increase competitiveness, extra service is needed for the customers. Before giving service, online games provider has to know what factor that motivates player to buy online games and virtual items that are presented in order to increase competitiveness. The research is done by using case of online games perfect world, where the area of respondents is Jakarta and the age ranges between 15 to 24 . This research involves survey for 186 respondents in which 30 respondents are for pilot test while 156 are for actual test. The data processing is used SEM which the measurement variables consist of effort expectancy, performance expectancy, perceived value, enjoyment story, enjoyment length, enjoyment graphic, enjoyment control, customization, purchase intention and actual purchase behavior. The result of research shows that motivation factor that has high effect to purchase intention is perceived value, enjoyment story, enjoyment length, enjoyment control and customization. While, purchase intention affects actual purchase behavior significantly.
\end{abstract}

Keywords: Online games; SEM virtual items; Purchase behavior; perfect world

\section{INTRODUCTION}

Technology is developing and internet becomes one of choices for people to interact with each other. With internet, human can interact with others by online. One of the famous online contents is online games, where humans not only play with computer, but they also can be connected with others through internet [1]. Unlike traditional games that online one or two players that can play game in computer, online game allows many players in whole world to play together in one game server through internet.

Online games are developing and have many users. Game markets in whole world are predicted to grow from $\$ 3.4$ billion in 2005 to be more than $\$ 13$ billion in 2011. This thing shows that there are increases in potential of online game users [2]. By seeing increase in potential of online user, then that thing causes many companies involve themselves in this industry [2]. With high competitiveness, company must make players (consumers) loyal, and have motivation to keep on playing. So that online games players have intention to do purchase from game and virtual items presented by game provider, then it must be examined to find what factors cause players to have intention to do online games and virtual items purchase. Therefore, it is needed an extra service that is for its customers and a standardization of service for customers so they are motivated to provided online games.
Service for client is an important aspect in IS (Information system) function. Service is different from product because service is related with performance and process not concrete thing that can be tested, calculated, and measured. Therefore, there must be product revision so service becomes maximal.

Because of high development of online games especially in Indonesia and based on background elaborated above, then problem formulation that is discussed in this thesis is what are factors that affect online game and virtual items purchase intention?

Benefit from this research is to find out motivation factors that affect intention of online games player to do purchase. The result of this research can give useful information for online games provider especially when developing online games and giving virtual items that will be bought by players. The other benefits of this research are that company can determine the standardization according to requirement that must be fulfilled by game developer in excellent service for consumers, company can know what makes customers intend to buy game that they provide, so it can innovate by revising the appearance, avatar, plot and others in online game which they make. By knowing what is wanted and customers' opinion, it is hoped that company of online games provider can revise or innovate so it can increase customers' satisfaction so for next it can increase revenue for company of online 
games provider and for online games developer, can be a reference in making online games that give qualified service. Other for company, and online games players, it can be reference or benchmark to know what is their motivation to play online games.

Scope of this research is online games. In research, which is done using war games, perfect world where in game, player can by virtual items. Population that are taken for this research is Indonesian with sample taking of Jakarta people that have ever (at least once) to often played online games. The players' ages range from 15 to 24 years [3-7].

\section{METHOD}

The used research methodology is survey method where survey is done to online games users. Survey is done by spreading questionnaire to online games users Used research model is quantitative model, so statistic will be used to process the obtained data. The population target in this research is online games users. According to Ref. [3], the players' ages range from 15 to 24 years.

Sample selection method is done randomly (probability sampling). Sample taking technique is done with Slovin method:

$$
n=\frac{N}{N \cdot d^{2}+1}
$$

Where,

$\mathrm{n}=$ amount of sample

$\mathrm{N}=$ amount of population (1000 people)

d2 = precision (is set 10\%, trust level $90 \%$ )

Based on that formula, it is obtained amount of sample about 90.9 respondents. Needed sample in SEM analysis is $5 \mathrm{x}$ indicator variable which means: $5 \times 30=150$. For questionnaire testing purpose, it is needed respondents about 30 respondents from 150 respondents that are taken from sample done randomly. While for real research, it uses about 120 respondents from 150 respondents that are taken from sample done randomly. Data analysis uses SEM method. This technique is chosen because there is consideration of examined variables, which are latent variable that can't be measure directly, so it need to do confirmatory factor analysis (CFA). CFA is used to test pattern of relation between several latent construct.

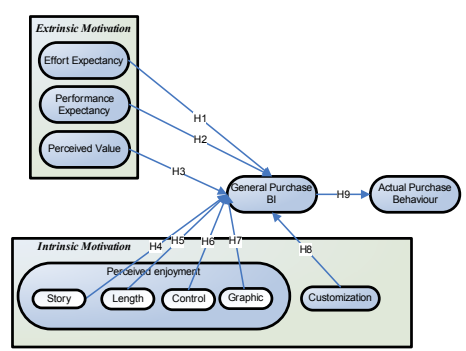

Fig 1: Research model
Factors that affect in this research is modification result from several journals, which are:

\section{Effort Expectancy (EF)}

The export expectancy is addressed for several individual's trust levels about virtual item purchase in virtual world where they will be freed from physic or mental effort [7]. Interface drafting is designed well, so players only need little time to find and buy items accordance to they want. Moreover, easiness in using trade platform to buy virtual item only through observation is important thing [8].

\section{Performance Expectancy (PE)}

It is addressed to several individual's trust levels about usage of virtual platform will help them to get virtual items that they want in virtual world.

\section{Perceived Value (PV)}

This is defined as assessment of consumers wholly from utility of a product based on perception about what is received and what is given. Consumers measure difference from value that is felt based on benefit that is given and expense that is felt (extepence that must be paid). There are four definitions od perceived value: cheap price, whatever that is wanted from the product, quality that is obtained consumers suits with the price that they pay and what do consumers get after what they give?

\section{Perceived Enjoyment}

This is how far pleasure can be lowered from participation in virtual world. Enjoyment or pleasure is defined as how far an activity that is done is considered as giving enjoyment and pleasure in themselves. In this enjoyment, it is divided into several discussion divisons:

- $\quad$ Story (ES)

Like in film, online games have story that player can attach as fantasy and their desire. Like presented in film, novel and opera, story is also key component in a online game [9]. It is because of interesting story, then that online games can motivate player to explore the game and keep on returning to virtual world to see game character until end. Players will build a character that determines its game by acting in dimension and time from virtual world. In this thing, players consider game as an interesting and entertaining thing.

- $\quad$ Graphics (EG)

Interface user in online games is an important thing in presenting of that player. Graphic aspect from online game refers to visual information that is obtained by players during match which is in form of picture or photo. Online games are considered as a visual experience mainly to entertain and the main goal in developing online 
games is to increase technology to present visual for customers. One of the results of this visual is produced avatar. Consumers can notice avatar's changing that they choose and the thing can make players feel real game and they can enjoy the game.

\section{- $\quad$ Length (El)}

This is amount of average time that is given to players to achieve victory. So that players can enjoy online games, it is really important to integrated the needed length of time for story background in game (along with matching the needed length of time in games so the story isn't too long or too short, because story that is too long can weaken that game). In the process of achieving a victory, it should be set clearly like period that is ascertained reasonably.

\section{- $\quad$ Control (EC)}

This refers to mechanism that allows players to process and direct a game by using keyboard and mouse. The effect from this control is it eases players in playing so control has to be designed easy to be understood way, way to be learnt and way to be used.

\section{Customization (CZ)}

Virtual item function is it can increase ability wholly if a character to compete while decorative virtual items help players to adjust players' character appearance. Some categories of customization are appearance, accessory, provocation, group domination and color outline.

\section{General Purchase Behavior Intention (PI)}

Intention to repurchase is intention measurement of consumers to purchase online. Attitude of purchase intention refers to subjective probability and someone's involvement in getting virtual items that is wanted through purchase in virtual world. This attitude of purchase intention show intention of individual to purchase items or service that is wanted through web although they do not know where they will do the purchase.

\section{Actual Purchase Behavior (AP)}

The indicator for actual purchase behavior is frequency of customers' transaction (online game users) and how much money that is spent to play and purchase items from online games.

Hypothesis in this research are:

H1: EF affects positively on PI online games. $\mathrm{H} 2$ : PE affects positively on PI online games. H3: PV affects positively on PI online games. H4: ES affects positively on PI online games. H5: EL affects positively on PI online games. H6: EC affects positively on PI online games. H7: EG affects positively on PI online games.
H8: CZ affects positively on PI online games. H9: PI affects positively on AP online games.

\section{RESULTS AND DISCUSSION}

In the beginning, as pilot test questionnaire is given to 30 respondents. After that, there will be test to 30 questions that are submitted using SPSS to test validity and reliability of the data. It turns out there are 2 invalid question, so that questions in questionnaire that are submitted for the rest of respondents are 28 question.

For actual data, questionnaire is given to 200 respondents and from 200 questionnaires that are spread, there are returned 156 questionnaires. From the obtained data, respondents are categorized based on their gender (male: $82 \%$, female:18\%), age (resulted the highest percentage is 14-21 years which is $71 \%$ ), job (resulted the highest percentage is university students which are 56\%), last education (resulted the highest percentage is high school or equal which is $72 \%$ ), time as online games users (resulted the highest percentage is $>2$ years which is $28 \%$ ), and frequency of playing in a month (resulted the highest percentage is $2-5$ times in a month which is $37 \%$ ).

Here is the result of processing data using SEM:

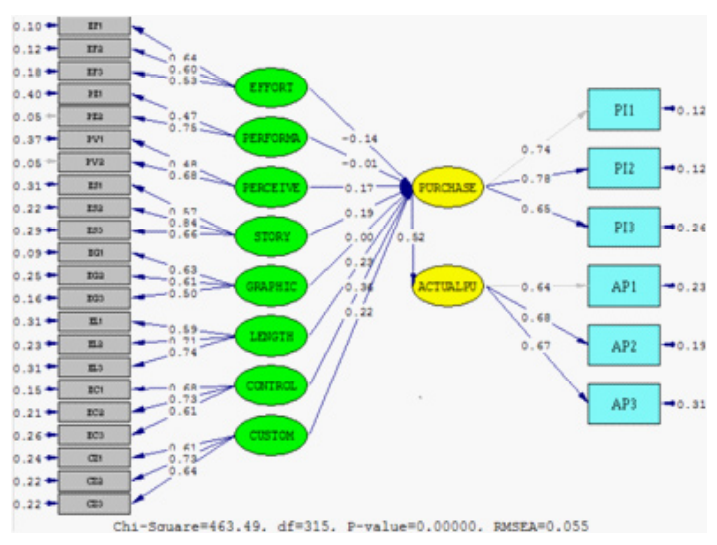

Source: data processing

Fig 2: Estimate Diagram

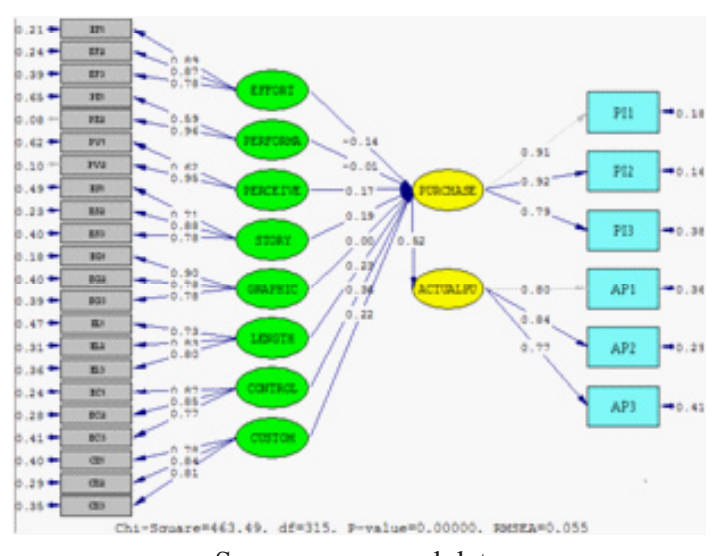

Source: processed data

Fig 3: Standardized Solution Diagram 


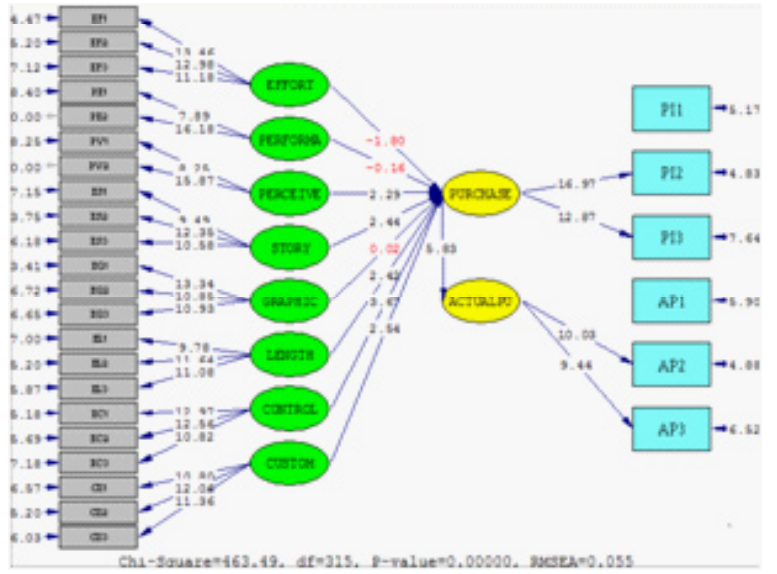

Source: data processing

Fig 4: t-Value Diagram
After checking, researcher doesn't find any offending estimates in CFA measurement, next is validity and reliability testing from each question:

Table 1: Validity and Reliability testing

\begin{tabular}{|c|c|c|c|c|c|c|c|}
\hline & & \multirow{2}{*}{ SLF } & \multirow{2}{*}{$\mathbf{R 2}$} & \multirow{2}{*}{ Error } & \multirow{2}{*}{ Description } & \multicolumn{2}{|c|}{ Reliability } \\
\hline & & & & & & $\mathrm{CR}$ & $\mathrm{VE}$ \\
\hline \multirow[t]{3}{*}{ EFFORT } & $\mathrm{EF} 1$ & 0.89 & 0.79 & 0.11 & Good validity & 0.93 & 0.83 \\
\hline & EF2 & 0.87 & 0.76 & 0.13 & Good validity & & \\
\hline & EF3 & 0.78 & 0.61 & 0.22 & Good validity & & \\
\hline \multirow[t]{2}{*}{ PERFORMA } & PE1 & 0.6 & 0.35 & 0.41 & Good validity & 0.84 & 0.74 \\
\hline & PE2 & 0.96 & 0.92 & 0.04 & Good validity & & \\
\hline \multirow[t]{2}{*}{ PERCEIVE } & PV1 & 0.62 & 0.38 & 0.38 & Good validity & 5 & 0.75 \\
\hline & PV2 & 0.95 & 0.9 & 0.05 & Good validity & & \\
\hline \multirow[t]{3}{*}{ STORY } & ES1 & 0.71 & 0.51 & 0.29 & Good validity & 0.9 & 0.74 \\
\hline & ES2 & 0.88 & 0.77 & 0.13 & Good validity & & \\
\hline & ES3 & 0.77 & 0.59 & 0.23 & Good validity & & \\
\hline \multirow[t]{3}{*}{ GRAPHIC } & EG1 & 0.9 & 0.82 & 0.1 & Good validity & 0.92 & 0.79 \\
\hline & EG2 & 0.78 & 0.6 & 0.22 & Good validity & & \\
\hline & EG3 & 0.78 & 0.61 & 0.22 & Good validity & & \\
\hline \multirow[t]{3}{*}{ LENGTH } & EL1 & 0.73 & 0.53 & 0.27 & Good validity & 0.9 & 0.74 \\
\hline & EL2 & 0.83 & 0.69 & 0.17 & Good validity & & \\
\hline & EL3 & 0.8 & 0.64 & 0.2 & Good validity & & \\
\hline \multirow[t]{3}{*}{ CONTROL } & $\mathrm{EC} 1$ & 0.87 & 0.76 & 0.13 & Good validity & 0.92 & 0.8 \\
\hline & $\mathrm{EC} 2$ & 0.85 & 0.72 & 0.15 & Good validity & & \\
\hline & $\mathrm{EC} 3$ & 0.77 & 0.59 & 0.23 & Good validity & & \\
\hline \multirow[t]{3}{*}{ CUSTOM } & $\mathrm{CZ1}$ & 0.78 & 0.6 & 0.22 & Good validity & 0.91 & 0.77 \\
\hline & $\mathrm{CZ2}$ & 0.84 & 0.71 & 0.16 & Good validity & & \\
\hline & $\mathrm{CZ3}$ & 0.81 & 0.65 & 0.19 & Good validity & & \\
\hline \multirow[t]{3}{*}{ PURCHASE } & EF1 & 0.91 & 0.82 & 0.09 & Good validity & 0.95 & 0.86 \\
\hline & $\mathrm{EF} 2$ & 0.92 & 0.84 & 0.08 & Good validity & & \\
\hline & EF3 & 0.79 & 0.62 & 0.21 & Good validity & & \\
\hline \multirow{3}{*}{$\begin{array}{l}\text { ACTUAL } \\
\text { PU }\end{array}$} & AP1 & 0.8 & 0.64 & 0.2 & Good validity & 0.91 & 0.76 \\
\hline & $\mathrm{AP} 2$ & 0.84 & 0.71 & 0.16 & Good validity & & \\
\hline & AP3 & 0.77 & 0.59 & 0.24 & Good validity & & \\
\hline
\end{tabular}


The obtained result is questions that are submitted are valid and reliable. Next step is the goodness of fit testing:

Table 2: Goodness of fit testing

\begin{tabular}{llll}
\hline \multicolumn{1}{c}{$\begin{array}{c}\text { GOF } \\
\text { Size }\end{array}$} & \multicolumn{1}{c}{ Value } & $\begin{array}{c}\text { Standard value } \\
\text { for good fit }\end{array}$ & Conclusion \\
\hline $\begin{array}{l}\text { Chi Square / } \\
\text { pvalue }\end{array}$ & $463486 / 0.000$ & P value $<0.05$ & Not good \\
NCP & 148.486 & $94.901 ; 210.061$ & Good fit \\
RMSEA & 0.055 & RMSEA $\leq 0.08$ & Good fit \\
NFI & 0.902 & NFI $\geq 0.90$ & Good fit \\
NNFI & 0.952 & NNFI $\geq 0.90$ & Good fit \\
CFI & 0.96 & CFI $\geq 0.90$ & Good fit \\
IFI & 0.961 & IFI $\geq 0.90$ & Good fit \\
GFI & 0.824 & GFI $\geq 0.90$ & Marginal fit \\
AGFI & 0.773 & AGFI $\geq 0.90$ & Not good \\
RFI & 0.882 & $0.8 \leq$ NFI $\leq 0.90$ & Good fit \\
\hline
\end{tabular}

Source: data processing

The evaluation result of goodness of fit model shows that almost all fit parameter models meet the requirement of goodness of fit except $p$ value of chisquare that still has $<0.05$ value and $\mathrm{AGFI}<0.90$. One fit index is in marginal fit level, which is GFI.

In figure 4 (t-value diagram), significant relation will be marked with t-value with black color which is $>=1.96$ value, while the ones with red color is insignificant relation. Based on that, it can be concluded that:

Table 3: Frequency gender type of the respondents

\begin{tabular}{clccc}
\hline Hypothesis & \multicolumn{1}{c}{ Path } & t-Value & Estimate & Result \\
\hline H1 & $\begin{array}{l}\text { Effort Expectancy -> } \\
\text { Purchase Intention }\end{array}$ & $-1,8$ & $-0,14$ & Rejected \\
H2 & $\begin{array}{l}\text { Performance } \\
\text { Expectancy -> } \\
\text { Purchase Intention }\end{array}$ & $-0,16$ & $-0,01$ & Rejected \\
H3 & $\begin{array}{l}\text { Perceived Value -> } \\
\text { Purchase Intention }\end{array}$ & 2,29 & 0,17 & Accepted \\
H4 & $\begin{array}{l}\text { Enjoyment Story -> } \\
\text { Purchase Intention }\end{array}$ & 2,24 & 0,19 & Accepted \\
H5 & $\begin{array}{l}\text { Enjoyment Graphic -> } \\
\text { Purchase Intention }\end{array}$ & 0,02 & 0 & Rejected \\
H6 & $\begin{array}{l}\text { Enjoyment Length -> } \\
\text { Purchase Intention }\end{array}$ & 2,42 & 0,23 & Accepted \\
H7 & $\begin{array}{l}\text { Enjoyment Control -> } \\
\text { Purchase Intention }\end{array}$ & 3,67 & 0,36 & Accepted \\
H8 & $\begin{array}{l}\text { Customization -> } \\
\text { Purchase Intention }\end{array}$ & 2,54 & 0,22 & Accepted \\
H9 & $\begin{array}{l}\text { Purchase Intention -> } \\
\text { Actual Purchase }\end{array}$ & 5,83 & 0,52 & Accepted \\
\hline
\end{tabular}

Source: research data

\section{CONCLUSION}

The result obtained in hypothesis 1 cannot support the fact that effort expectancy affects significantly towards purchase intention. Researcher analyze that easiness level that is felt by users can't increase motivation on purchase intention of online games and virtual items. This thing can be caused by different easiness level of each person, if online games users have been used to and had curiosity to find out the usage, then easiness level is not a problem.

The obtained result from hypothesis 2 can hardly by supported that performance expectancy affects significantly purchase intention. Researcher analyzes that individual's level of trust towards usage of online games, where they can achieve benefit can't increase motivation on purchase intention of online games. This thing can be caused by virtual items that are wanted can be used with several ways like purchase from other players or purchase directly through the online games.

The result of hypothesis 3 is supported by the fact that perceived value is related significantly on purchase intention. The result of hypothesis 4 is supported by the fact that enjoyment story is related significantly on intention to play. The result that is obtained in hypothesis 5 can hardly be supported that enjoyment graphic is related significantly on intention to play. This thing can be caused by users, who feel they need entertainment so they don't care about the produced graphic.

Result of hypothesis 5 is supported by the fact that enjoyment length is related significantly on intention to play. This thing can be caused by users, who want to know exactly when they will get victory or level up.

The result of hypothesis 6 is supported by the fact that enjoyment control is related significantly on intention to play. This thing can be caused by users, who want to get easiness in playing online games so the used buttons don't trouble them.

The result of hypothesis 7 is supported by the fact that enjoyment control is related significantly on intention to play. This thing can be caused by users, who want to get easiness in playing online games so the used buttons do not trouble them.

The result of hypothesis 8 is supported by statement of that fact that customization is related significantly on purchase intention. This thing can be caused by users, who want to change appearance or character so it is different from others.

The result of hypothesis 9 is supported by the fact that purchase intention is related significantly actual purchase behavior. With purchase intention from users based on variables above, then this thing can cause users to purchase online games or virtual items provided by online games providers.

From conclusion above, it can be seen that enjoyment control has the highest significance for 
purchase intention. Online games providers are recommended to more pay attention to motivation factors that strengthen purchase intention like perceived value, enjoyment story, enjoyment length, enjoyment control and customization.

According to this research result, in next research can be added new factor to enrich used model in this research. With new researches that add new indicator, then model can be more perfected. If the obtained result is proved same, then that model has high consistency in Jakarta area.

\section{REFERENCES}

[1] D. Choi, \& J. Kim. "Why People Continue to Play Games: In Search of Critical Design Factors to Increase Customer Loyalty to Online Contents," Cyber Psyhology \& Behavior, vol 7, pp. 11-24, 2004.

[2] Y. S. Wang, M. C. Wu, \& H. Y. Wang, "Investigating the determinants and age and gender," British Journal of Educational Technology, vol. 40, pp. 92-118, 2009.

[3] C. S. Wu, \& L. F. Tsai, "The Research on Relationship among Online Game Endorsement, Adolescent Involvement and Game Purchase Intention," International Journal of Management, Economics and Social Sciences (IJMESS), vol. 2, pp. 205 - 216, 2013.

[4] C. L. Hsu, \& H. P. Lu. (2004). "Why Do People Play OnLine Games? An Extended TAM with Social Influences and Flow Expericence," Information and Management, vol. 41, pp. 853 - 868, 2004.

[5] C. S. Wan, \& W. B. Chiou, "The Motivation of Adolsecents Who Are Addicted to Online Games: A Cognitive Perspective," ADOLESCENCE, vol. 42, pp. 179-197, 2007

[6] G. Yue, Barnes, J. Stuart, "Why Do People Buy Virtual Items in Virtual Worlds? An Empirical Test of a Conceptual Model," 17th European Conference on Information Systems, pp. 49-61, 2009.

[7] G. Yue, Barnes, J. Stuart, "Explaining Purchasing Behavior Within World of Warcraft," Journal of Computer Information Systems, vol. 52, pp. 18, 2012.

[8] S. Venkatesh, S. Amy, \& R. Arvind, "Customer Satisfaction and Loyalty in Online and Offline Environments," International Journal of Research in Marketing, vol. 20, pp. 153 - 175, 2003.

[9] P. Celia, "Game Noir- A Conversation with Tim Schafer," Game Studies, vol. 3, 2003, Retrieved from: http://www.gamestudies.org/0301/pearce/, 